\title{
Towards Change Management in Tourism: the Evidence from North Macedonia
}

\author{
Snezana Hristova / Ana Tomovska Misoska / Dimitar Kovachevski \\ e-mail: shristova@uacs.edu.mk, tomovska@uacs.edu.mk, dimitar.kovachevski@uacs.edu.mk
}

School of Business Economics and Management, University American College, Skopje, Macedonia

Hristova, S., Misoska, A. T., \& Kovachevski, D. (2019). Towards Change Management in Tourism: the Evidence from North

Macedonia. Czech Journal of Tourism, 8(1), 3-15. DOI: 10.2478/cjot-2019-0001.

\begin{abstract}
This paper investigates the perceptions and practices of managers of the tourism sector with regards to change management. It has been suggested that change management is an inevitable element for tourism businesses to increase their speed of response to market and competitive changes. Logically, it can be argued that tourism managers are best placed to initiate and facilitate this change. The primary data were obtained through a survey, carried out in tourist agencies in the Republic of North Macedonia and evaluated by using the tools of descriptive statistics and the methods of comparison, induction, deduction and synthesis. The key findings indicate that the majority of the respondents were familiar with the term change management and they implemented the change management practices. However, work still needs to be done to help the remaining companies to understand the necessity of changing the paradigm. Regarding the practical implications, this paper can serve as a stepping stone for future research that can uncover the potential, experiences and outcomes of change management in the tourism sector in the country.
\end{abstract}

\section{Keywords}

change management, tourism, tourist agency, organizational model, North Macedonia

JEL classification: L20, L21, L22 


\section{Introduction}

Today managers are faced with dynamic, confusing and threatening environments where the only constant is a change. Because of the rapid changes in technology, different needs of customer services and choices, increasing input costs and complicated products, businesses are operating in a difficult situation, complex decision making and implementation of a wide variety of change management strategies that must be adaptive and responsive to the change. This position can be well integrated in one of the most recognized Darwinian terms 'the survival of the fittest' or paraphrased in the following statement (Holbeche, 2015): It is not the strongest or the most intelligent who will survive but those who can best manage the change. In other words, in order to be competitive in business, it is essential to respond to changes in an adequate, effective and rational way.

The above arguments are of great relevance to the tourism industry, which is characterized with an increasingly dynamic and complex environment, whose evolution and shifts have a major influence on the ability of the businesses to compete. Pressures for the change within tourism businesses are very complex, both internal and external in nature. War, terrorism, political disturbance, airline restructuring, have made a deep impact on tourism businesses, while dynamic and structural changes in consumer behaviour patterns, international competition, technology development, social and environmental responsibility and other factors have brought on an increase in insecurity (Shivappa, 2015). The first decade of the twenty-first century also brought on a significant strategic shift from mass tourism towards the development of alternative forms of tourism and influenced new patterns in the tourist demand characterized by constant changes of the tourist needs and motives. Apart from this, tourism itself is a complex product and the new millennium has influenced new management imperatives such as the need for a strong ability to adapt as the change is essential for the survival of the business.

This paper aims at deepening the understanding of the meaning of the change and experiences of the change among managers and owners of tourist agencies in the Republic of North Macedonia. Moreover, the main motivation was to explore the perceptions and readiness of managers to cope with the change. Despite the fact that the total contribution of tourism to the country's GDP is relatively small in comparison to the other countries in the region, tourism still plays an important part in the economic development of the country. According to the WTTC (2017), the contribution of travel and tourism to the GDP (\% of GDP) of North Macedonia has fluctuated substantially in recent years, but it tended to increase in the period 1999-2018, ending at $7.2 \%$ in 2018. Interesting is that in 2013, the country was named one of Lonely Planet's top ten destinations, with good potential for tourism, starting from a relatively low level, but still too traditional, i.e. it mostly consists of summer mass tourism and winter tourism as major forms of tourism. As a result of this tourist offer, it is normal to have a weak or insufficient development of the country's tourism. For North Macedonia as a tourist destination that wants to leverage economic benefits from tourism, it is important to at- 
tract foreign tourists, but at the same time to create a strategy for keeping domestic tourists and thus their higher income to be spent in Macedonian tourist capacities and not abroad. Given the changed customer preferences, North Macedonia should not focus on re-developing the massive type of tourism. Instead it should follow the new trends in the tourism market and direct its products towards the alternative and adventurous types of tourism, according its natural landmarks. Tourism related firms and destinations lose their competitiveness and enter a vicious cycle of decreasing profitability, shrinking investments and low competitiveness if they do not constantly adapt their structure to the new market requirements, to the technological developments and to the environment. Structured change management is therefore necessary and should be supported (Keller \& Bieger, 2010). In this context, this paper contributes to the existing research in this field and represents one of the pioneer attempts in the case of North Macedonia.

\section{Theoretical basis}

Change management refers to the adoption of an idea, procedure, process or behaviour that is new to an organization (Pierce \& Delbecq, 1977). Moran and Brightman (2001) define change management as a process of continually renewing an organization's direction, structure, and capabilities to serve the ever-changing needs of external and internal customers. Burnes (2000) reports that change is a multi-level, cross-organizational process that unveils a disorganized and incompetent trend over a period and comprises a series of interlocking projects. He also points out that organisations that effectively manage the change have a greater advantage over their competitors. However, according to Stewart and Kringas (2003), 'change management, like 'change', is a difficult term to define. Struckman and Yammarino (2003, p. 10) consider the change as a process or an action. They define the organizational change as a managed system, process and/ or behavioural response over time to a trigger event. Prosci (n.d.), the world leader in benchmarking research and change management products, defines change management as a structured process and a set of tools combined under one application, leading the human side of the change in order to achieve the desired results. Robbins (2003) defines the change as making things different. Garber (2013) mentions that the change is inevitable in the workplace. Thus, the role of the manager is to embrace the change by making the transition process easier. It can be concluded that change management becomes an inevitable process and refers to a proactive approach about how the change is treated within an organization.

Many scholars have suggested that change management can be applied at two main levels. According to Hiatt and Creasey (2012), the basic level is individual change management, which includes managers coaching to help their employees through the change, holding focus conversations with employees, especially resistant ones, determining diagnose gaps in the program of managing the change for each department, and identifying corrective actions, which are based on the desired results. What is required here is for individuals to be managed with support and care to facilitate the change successfully. 
Besides teaching them good tools and techniques, it is also crucial to understand their roles through the change process (Kunze et al., 2013). The other level entitles to organizational change management are defined as the manager's perspective from the top looking down on the organization (Mou, 2013). Thus, the individual change management process should help the organization to face the needed change easily and successfully. It includes organizational tools such as communications and training the overall culture of the organization.

The fundamental key for the change agent to navigate a team through uncertainty is to identify the distinguishing characteristics of change management. To some extent, it is a process analogous to a temporary operation. Managerial implications for the organizational change seem to restructure and to redefine the operational performance (Kale, 2005). Some scholars (Kanter, Stein, \& Jick, 1992) argue that leaders may function as the change agents; they are the individuals responsible for the change strategy and implementation. However, it is noted that although the responsibility for managing the change does not fall on the employees, their responsibility is to provide a $100 \%$ performance and do their best. The responsibility for managing the change falls primarily to the management team and the managers. They are also faced with the fact that people in the organization must be involved in the change management process since if the organization or the management team imposes these changes on the employees, there might be difficulties for them to understand them.

As the organizational changes have become more frequent as a necessity for survival, the resistance of employees in this sector has become an important human resources management function and a priority for the top management to increase chances of success of different change projects (Tang \& Gao, 2012).

However, managing employees' resistance during the organizational change requires an effective type of the change management processes (Jansson, 2013). In particular, communications from the right entity in the organization help improve the employees' response to the organizational change (Kotter \& Schlesinger, 2008).

One of the dominant perspectives within the "planned approaches' to change is Lewin's (1951) model of change, which argues that the change involves a three-stage process: unfreezing the status quo, then changing to the desired future state, and refreezing the new state (Vakery \& Antonio, 2010). The ADKAR model for managing the change stands for awareness of employees, their desire to change, their knowledge about the change, ability to change, and reinforcement to keep the change in place. This model can help managers to determine where their employees are in the change process. The Lewin's Model of Change perceives the change as the process which keeps the forces that affect the behaviour of the system stable (Duffy, 1996).

Kotter (1996) has also presented the change management model as a result of studying the change management practices in more than a hundred organizations. Kotter's model concentrates on making the change occur; highlighting the importance of the feeling about the necessity of the change in the organization, and highlighting the need of effective communication through the change process (Mou, 2013; Cameron \& Green, 2004). In his model, eight steps of the change process are: creating urgency as the most impor- 
tant step towards implementing the change strategy, forming a powerful coalition in the company and having strong leadership in order to convince people that the change is needed, creating a vision for the change which the employees within the company will understand and follow, communicating the vision, removing obstacles, creating short term goals to build on the change and making the changes stick. In other words, you have to make sure that these changes are implemented in the corporate culture.

The Kubler-Ross Change Curve is a model for navigating transition from the change initiation to reaching organization's overall goals. It is very useful to understand how people navigate the change. Building structures to help people move through the change accelerates the adaptation process as many people experience feelings of loss during the change (Anastasia, 2015). At the beginning of the process, the employees are in shock or denial and are not prepared to undergo the change and adapt to something new. In the second stage of the implementation of the change when employees have a more clear vision of what lies ahead would feel some fear, because they have been comfortable for some period of time with the situation in the company and now they need to change and learn something new. The third stage is when employees finally see and understand the change in the organization; at this stage, they may try to bargain with the management, which means that they will try to learn only what is important for them. Because of that, management should encourage them to make the best of the training in order to successfully implement the change. The fourth stage is characterized by low mood or a lack of energy because the learning phase is not always a very happy and comfortable zone for some of the employees. In the fifth stage, employees have finished with training and learning and this is the stage where some of the employees fully understand and implement the change, while others do not accept the need for the change and might resign from the company.

To conclude, all of the above mentioned models have a unique approach to change management, pointing out a variety of different aspects. Thus, they should be considered as complimentary to each other because due to their complexity, change management requires knowledge of different perspectives, models and approaches.

\section{Methodology}

The research was conducted through a questionnaire with closed answers. There were 6 questions with the data about the company such as the years of operation, the number of employees and similar types of questions. The other questions described opinions and experiences about change management.

The questionnaire was answered by 25 respondents (sent to 50 respondents) from tourist agencies in the Republic of North Macedonia. Most of the agencies that provided the answer to the question were located in the city of Ohrid which is the best known tourist destination in the country ( $50 \%$ or 12 companies), followed by those located in the capital Skopje ( $20.9 \%$ or 5 companies) and the rest were dispersed in other cities around the country. This distribution represents the location of the tourist agencies in 
the country. The small sample size is a limitation to the research as the generalisation of the findings resulted hampered, due to the lack of representativeness of the sample. The small sample size also impedes comparisons between the various types of tourist agencies as there are too few cases to compare. However, as this research is one of the first of its kind in the country, the results can be used for gaining an understanding into the process of change management among tourist agencies in the country and inspire further research in this field.

The majority of the respondents were professional managers $(45.8 \%$ or 11 respondents), followed by those who stated that they were both owners and managers $(37.5 \%$ or 9 respondents) and lastly those who were owners (16.7\% or 4 respondents). Thus, the sample offered a mix of respondents, both professional managers and owners of tourist agencies.

The majority of the respondents came from the agencies operating for more than 10 years ( $40 \%$ or 10 responses), followed by those that exist between 1 and 5 years (32\% or 8 companies) and those that operate between 5 and 10 years (28\% or 7 companies). This gives a balanced representation of the companies at various stages of operation. Most of the agencies work in outbound and inbound tourism (44\% or 11 companies), followed by those only engaged in inbound tourism (36\% or 9 companies) and those engaged only in outbound tourism (20\% or 5 companies).

All the companies in the sample belong to the small enterprises sector. The majority of the surveyed companies have less than five employees ( $64 \%$ or 16 companies); while $16 \%$ ( 4 companies) have between 5 and 10 employees and 20\% (5 companies) have more than 10 employees.

\section{Results}

The results section presents the organizational setup and functioning of the agencies and their experience with the change and change management. The agencies provided an insight into the organizational models that they employ using the typology provided by Marinoski (2008). As it can be seen from Table 1, most of them use a model of a travel agency with a network of business units (32\% or 8 companies). This means that they have a head office that controls the activities within the organization and also takes care of marketing management related activities. The second most used model is a classical model ( $28 \%$ or 7 companies) of a head office with several subsystems. A smaller number of companies chose another model. This means that the majority of the surveyed companies uses a model that provides some sort of insight into the market as there are sales agents and specialized department for sales and contact whilst the marketing is led by the head office. However, the second largest group uses a model that lacks an important aspect of the functioning for prosperity of the travel agencies and that is the marketing sector. The answers are only indicative due to the small sample size. However, according to Marinoski (2008), tourist agencies in the country as the most important intermediary in this process need to change towards adoption of marketing capabilities that can offer 
the right tourist products with proper promotional activities and together with the other players in the industry create competitive tourist offers.

Table 1 The type of the organizational model used

\begin{tabular}{|l|r|}
\hline $\begin{array}{l}\text { Classical model: a head office with several subsystems: commercial affairs, financial } \\
\text { bookkeeping, or legal. }\end{array}$ & $28 \%$ (7) \\
\hline $\begin{array}{l}\text { A model with marketing activities: all the subsystems from the classical model, plus } \\
\text { marketing unit. }\end{array}$ & $4 \%$ (1) \\
\hline $\begin{array}{l}\text { Model of marketing organization: it has two main sectors, general management and } \\
\text { marketing management, which are closely connected. }\end{array}$ & $8 \%$ (2) \\
\hline $\begin{array}{l}\text { Model of a travel agency with a network of business units: it has a head office which } \\
\text { controls all the activities in the organization, as well as the activities of marketing } \\
\text { management. }\end{array}$ & $32 \%$ (8) \\
\hline $\begin{array}{l}\text { Model of a travel agency without a network of business units: it has a central agency } \\
\text { organization that contains all the business units that are located in the head office } \\
\text { and marketing management sector. }\end{array}$ & $12 \%$ (3) \\
\hline $\begin{array}{l}\text { A model of a receptive organization: it has two main sectors, a receptive and } \\
\text { marketing sector. }\end{array}$ & $4 \%$ (1) \\
\hline $\begin{array}{l}\text { A model of an initiative organization: it has an initiative sector that is divided into two } \\
\text { departments. }\end{array}$ & \\
\hline
\end{tabular}

Source: Marinoski (2008)

One of the questions investigated the knowledge that the respondents have about the change in the tourism paradigms. When asked about their familiarity with the recent changes in the tourism market, more precisely, the shift from mass tourism to offering more alternative and adventure tourism, most of the respondents answered that they were moderately familiar with the changes ( $64 \%$ or 16 respondents), followed by those who claimed that they were extremely familiar with the changes (28\% or 7 respondents) and very few answered that they were somewhat familiar ( $8 \%$ or 2 respondents). None of them answered that they were not familiar or that they were slightly familiar. This points to a good level of familiarity with the newest developments in tourism, but there is still space for improvement as most of the respondents are moderately familiar with the new trends and they might need help in adjusting their offerings accordingly. This might serve as an impending factor in change management for those agencies that are not familiar with the new developments and it might mean that they need some help in updating their knowledge of the new developments in the field. This is even more important having in mind that the country has a potential for the alternative types of tourism (Marinoski \& Korunovski, 2012).

Change management in tourism agencies means that the Macedonian tourist agencies have to shift from the 'old' type of tourism, which means attracting tourists merely with the sun, sand and lakes, to the 'new' types of tourism, which means offering to the 
tourist alternative types of tourism, and forming a complex tourist product. One of the studies regarding the same topic was conducted by Cuculeski, Petrovska, and Mircevska (2015). It analysed the importance of alternative types of tourism for the development of the Macedonian tourist market and also the benefits for the tourist companies. The conclusion that was reached was that the companies and agencies which offered alternative types of tourism to their clients had $25 \%$ growth in their profit, which is a significant result.

The main interest of the paper is, however, the organizational change. Therefore, the respondents were asked to provide their opinions on their understanding of the meaning of the change based on their previous experiences. Only 18 respondents provided answers. Most of them perceived the change as a positive occurrence, as something that is necessary for success, as a pathway to development and improvement. Some connected the change to their everyday activities of keeping active, travelling and discovering. There was only one answer that shed a slightly more worrying tone to the term change emphasizing that it can be a terrifying thing, but something that has to be done, at the same time stating that small changes and adjustments happen all the time. What this means is that those people who answered the question had opinions in line with what the literature on the topic notes (Kale, 2005; Tang \& Gao, 2012).

The next question provides a deeper insight into what is change management for the respondents. It also tries to test whether the respondents are familiar with the term change management. The respondents were offered a set of options for answering this question. As it can be seen from Figure 1, for most of the respondents $(68 \%$ or 17 companies) change management means using a set of tools which are combined under one application which leads the people's side of the change in order to achieve some desired outcome or results. As this is one of the definitions of change management (Prosci, n.d.), the answer uncovers that the respondents are familiar with the term change management. The other answers were the overall change of the business model, change of processes and change of the management style. The results reflect that the term change management has different meaning for different people that were part of this research.

When asked about whether they have gone through a process of the change, $64 \%$ (16 companies) of the respondents answered positively and 16\% (4 companies) stated that it was very likely that they had gone through such a process. This means that a greater number of companies from the sample have experienced the change in recent years.

To understand the changes made, the respondents were asked about the type of changes that they carried out. Figure 2 presents the results. Most of the respondents highlighted that the change the management of their company went through was connected to the implementation of specific plans, followed by those who said that change management was connected to gathering and analysing feedback. The answers also show variability in what change management actually meant for the agencies involved in the research, based on their actual experiences. 
Figure 1 The meaning of change management

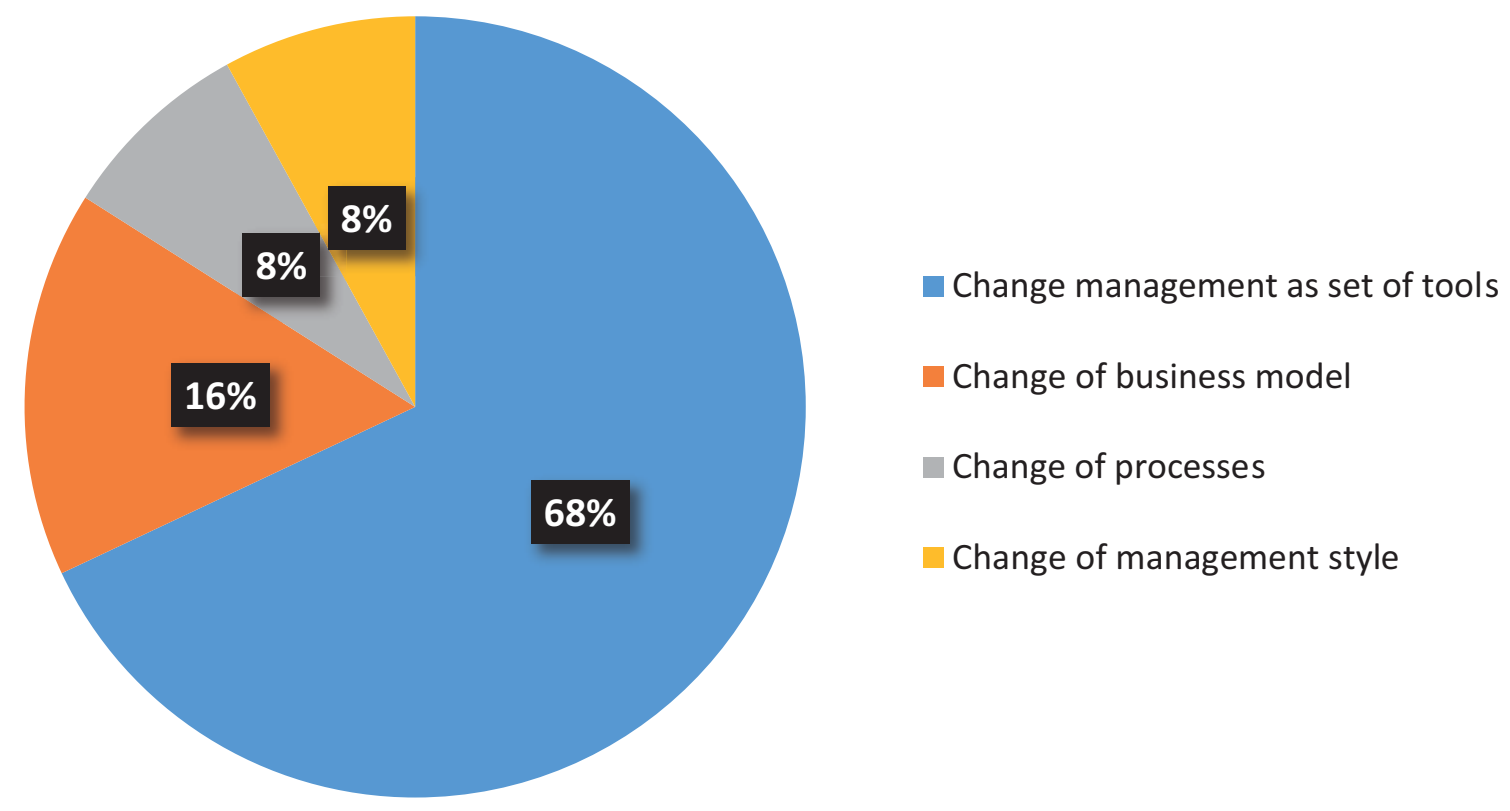

Source: own research

Figure 2 Activities carried out by the companies in the process of change management

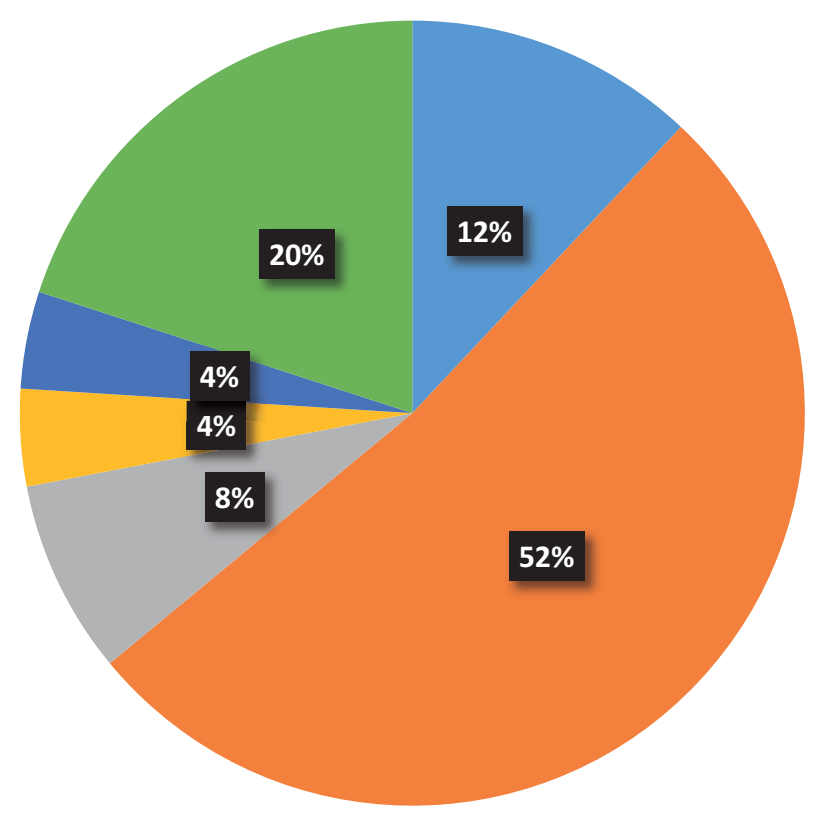
- Changing management processes
- Implementation of specific plans
Redefinition of strategy
- Planning by GM office
- Corrective actions
- Collect feedback

Source: own research 
To deepen the understanding of the change management process, the respondents were asked whether they had used a specific model in the change process. As it can be seen from Figure 3, most of the respondents that provided the answer to the question (17 companies) declared that they had used the ADKAR model (35,3\% or 6 companies) which is a change management model that is goal focused. According to the model, everything you do during the change management process is sequential: you must achieve cumulative goals during the process to achieve your overall change goal. An equal number of the respondents (29.4\% or 5 companies) used the Kubler-Ross five-stage model and Kotter's 8-step change model (1996). The Kubler-Ross model allows management to empathise with the employees as the change is implemented and sequentially lists the emotional and cognitive reactions of people to the change: Denial, Anger, Depression, Bargaining, and Acceptance. Kotter's model lists 8 steps in the change management process: creating a sense of urgency, building guiding coalitions, forming strategic visions and initiatives, enlisting volunteer army, enabling actions by removing barriers, generating short term wins and sustaining acceleration, actually institute the change. Only one company has used Lewin's model of change management that lists three stages: unfreeze, change and freeze. This again shows the variability of the experiences and opinions of the respondents in the sample.

Figure 3 Change models used

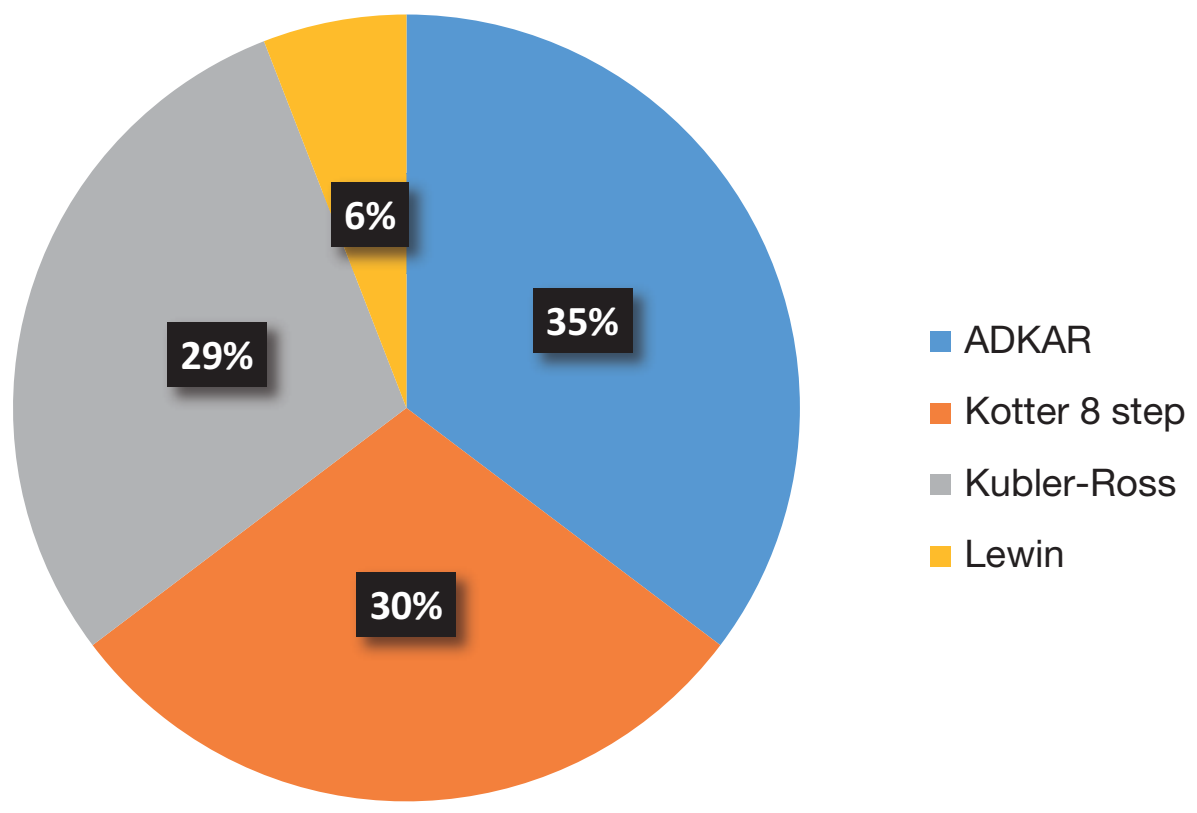

Source: own research 
During the change process, the reactions of the employees to the change are crucial for a successful implementation of the change. The majority of the respondents in the research $(66.7 \%)$ stated that their employees had hesitated to accept the change at the beginning but acknowledged the benefits of the change after it had been implemented. This is in line with what Tang and Gao (2012) acknowledge as reactions of the employees towards the change. Another 33.3\% stated that their employees had accepted the change immediately. None of the respondents expressed resistance to the change by the employee or turnover as a result of the change process.

This means that the respondents perceive that their employees are supportive of the change process, regardless of the small initial resistance. When asked about how successful they were in the implementation of the change, $56 \%$ (14 companies) stated that they had been successful in the implementation of the change and $44 \%$ (11 companies) stated that they had had moderate success in implementing the change.

Finally, the respondents were asked about the impact of the change on their respective companies, especially related to their performance on the tourist market. Most of the companies (52\%, 13 companies) had a moderate effect on their performance, followed by those which experienced a major effect on their performance (24\%, 6 companies), and $16 \%$ (4 companies) who were neutral in their answers. On the other hand, only one reported no changes to its performance.

\section{Conclusion}

This paper aimed at deepening the understanding of the meaning of the change and experiences of the change among managers and owners of tourist agencies in the Republic of North Macedonia. The literature reveals that in order to be able to compete and gain a competitive advantage, managers need to promote change management and implement the key organizational changes, because the tourism industry is in a state of unique change. The effective implementation of the change management practices enables businesses in tourism to increase their speed of response to the market and competitive changes. The organizational models of travel agencies depend on the heterogeneity of tourism demand in the constantly changing market. Therefore, travel agencies must follow the trends in the tourism market in order to set up an organizational hierarchy to meet the more specific requirements of tourists. It should be noted that none of the approaches and models for change management is the best one. The choice of a specific approach should be based on consideration of different environments, as well as upon integrating several models.

The present research showed that the majority of the respondents had been familiar with the term change management and they had implemented change management and had changed from managing the old style of tourism (sun, sea, sand) to the new style of tourism, which means offering more alternative types of tourism. However, work still needs to be done to help the remaining companies to understand the necessity of changing the paradigm. The answers also uncovered the variability in the experiences, 
meaning and understanding of the change management processes among tourist agencies in the country. However, the majority of the respondents have a positive understanding of the change management process.

Furthermore, while implementing the change management process, the majority of the companies followed the ADKAR model. Although they encountered a slight hesitation from the employees, the majority of the companies deemed their change management efforts to be successful, which is a positive trend. The results were presented collate for all agencies as the low sample size did not allow for a meaningful comparison to be made between the companies with different characteristics. Although this research had a small sample size, it still offers valuable insights into the experiences of tourist agencies in the country. As such it can serve as a stepping stone for future research that can uncover the potential, experiences and outcomes of change management in the tourism sector in the country.

\section{References}

Anastasia (2015). Understanding the Kubler-Ross Change Curve. Retrieved from https://www.cleverism.com/understanding-kubler-ross-change-curve/.

Burnes, B. (2000). Managing Change a Strategic Approach to Organisational Dynamics. London, UK: Pearson Education Limited.

Cameron, E., \& Green, M. (2004). Making Sense of Change Management: A Complete Guide to the Models, Tools Ẽ Techniques of Organizational Change. London, UK: Kogan Page Publishers.

Cuculeski, N., Petrovska, I., \& Mircevska, P. T. (2015). Emerging trends in tourism: need for alternative forms in Macedonian tourism. Review of Innovation and Competitiveness, 1(1), 103-113. DOI: $10.32728 /$ ric.2015.11/6.

Duffy, F. M. (1996). Designing high-performance schools: A practical guide to organizational reengineering. Delray Beach, FL: St. Lucie Press.

Garber, P. R. (2013). The Manager's Employee Engagement Toolbox, American Society for Training and Development, USA: ATD Press.

Hiatt, J. M., \& Creasey, T. J. (2012). Change Management: The people side of change. Fort Collins, CO: Prosci Learning Center Publications.

Holbeche, L. (2015). The Agile Organization: How to build an innovative, sustainable, and resilient business. London, Philadelphia, New Delphi: Kogan Page Limited.

Jansson, A. (2013) Mediatization and Social Space: Reconstructing Mediatization for the Transmedia Age. Communication Theory, 23(3), 279-296. DOI: 10.1111/comt.12015.

Kale, S. H. (2005). Change Management: Antecedents and Consequences in Casino CRM. UNLV Gaming Research Eं Review Journal, 9(2), 55-67.

Kanter, R. M., Stein, B. A., \& Jick, T. D. (1992). The challenge of organizational change: How companies experience it and leaders guide it. New York: Free press.

Keller, P., \& Bieger, T. (2010). Managing Change in Tourism: Creating Opportunities - Overcoming Obstacles. Berlin, Germany: Schmidt.

Kotter, J. P. (1996). Leading Change. Boston, MA: Harvard Business School Press. 
Kotter, J. P., \& Schlesinger, L. A. (2008). Choosing strategies for change. Harvard Business Review, 57(21), 106-114.

Kunze, F., Bohm, S. A., \& Bruch, H. (2013). Age, resistance to change, and job performance: Testing for a common stereotype. Journal of Managerial Psychology, 28(7/8), 741-760.

Marinoski, N. (2008). Turisticki Agencii. Ohrid: Fakultet za Turizam i Ugostitelstvo, Ohrid.

Marinoski, N., \& Korunovski, S. (2012). Tourism in Macedonia in changing environment. Procedia - Social and Behavioral Sciences, 44, 19-31. DOI: 10.1016/j.sbspro.2012.05.001.

Moran, J., \& Brightman, B. (2001). Leading organizational change. Career Development International, 6, 111-119.

Mou, I. K. (2013). Identifying and minimizing risks in the change management process: The case of Nigerian banking industry. Journal of Business Economics and Management, 1(6), 148-162.

Pierce, J. L., Delbecq A. L. (1977). Organization structure, individual attitudes and innovation. Academy of Management Review, 2, 27-37. DOI: 10.5465/amr.1977.4409154.

Prosci. (n.d.). What is change management. Retrieved from https://www.prosci.com/change-management/what-is-change-management.

Robbins, S. P. (2003). Organizational Behavior. San Diego, CA: Prentice-Hall.

Shivappa, R. (2015). Change Management - Concept, Process, Principles and Skills. Retrieved from https://www.slideshare.net/shivapparamakrishna/change-manage-dr-r-shivappa.

Stewart, J., \& Kringas, P. (2003). Change Management-Strategy and Values in Six Agencies from the Australian Public Service. Public Administration Review, 63, 675-688. DOI: 10.1111/15406210.00331.

Struckman, C., \& Yammarino, F. (2003), Organizational change: A categorization scheme and response model with readiness factors. Research in Organizational Change and Development, 14, pp. 1-50. DOI: 10.1016/S0897-3016(03)14079-7.

Tang, C., \& Gao, Y. (2012). Intra-department communication and employees' reaction to organizational change: The moderating effect of emotional intelligence. Journal of Chinese Human Resources Management, 3(2), 100-117.

Varkey, P., \& Antonio, K. (2010). Change Management for Effective Quality Improvement: A Primer. American journal of medical quality. The Official Journal of the American College of Medical Quality, 25, 268-273. DOI: 10.1177/1062860610361625.

WTTC. (2017). Travel and Tourism: Global Economic Impact and Issues. Retrieved from http:// mindersgroup.net/wp-content/uploads/2017/07/2017-Tourism-Global-Economic-Impact-andIssues-2017.pdf. 